\title{
Gall-inducing insects and plants: the induction conundrum
}

\author{
Anantanarayanan Raman* \\ CSIRO (Health and Biosecurity), Underwood Avenue, Floreat Park, WA 6014 \& Charles Sturt University, PO Box 883, \\ Orange, NSW 2800, Australia
}

Galls induced by insects and mites (insects, hereafter) have been a subject of interest to insect ecologists because of the unusual habit of gall induction and for their tightly connected relationships. These specialist insects and mites have been explored to explain the nature of interactions between them and the plants by entomologists, ecologists and plant physiologists over the last two centuries. However, the questions why only certain insect taxa induce galls on specific species of plants and how galls are induced remain challenging. Whereas several efforts made across the world implicate plant-growth regulators (PGRs) in answering the question on how galls are induced, this article emphasizes the establishment of a metaplasied cell at the location where the tip of the chitinous mandible or ovipositor first hits in the plant. In the light of the differentiation of a metaplasied cell, the earliest plant response, it is but critical to evaluate the physiology of that cell and the 'new' physiological events triggered around it, heralding gall initiation. PGRs certainly play a role in gall growth, but only during later stages. This article does not answer the question on how galls are induced. However, it brings to light the gaps that need to be addressed in future in the backdrop of the efforts made over the years. Since we need to deal with the physiological changes that occur in a metaplasied cell and a few adjacent cells, the use of sophisticated optical equipment and pertinent software to achieve a structured and articulate explanation impresses as the way to go.

Keywords: Cell-wall debris, chitinous mandible, gall induction, pathogenic fungi, plant-growth regulators.

INSECTS and mites (hereafter 'insects') and the galls they induce are known presently far more than before ${ }^{1-4}$. The discovery of 'samurai' aphids and their unique behaviour among the gall-inducing Aphidoidea by Shigéyûki Aôki was a milestone event $t^{5,6}$ that stimulated similar explorations in other gall-inducing insect groups ${ }^{7}$. The co-evolutionary ecology of gall-inducing insects and their host plants is a widely pursued topic today ${ }^{8-11}$. Yet, the answer to the question on how galls are induced is in a mess. This article focuses on the above elusive question. It summa-

*e-mail: araman@csu.edu.au; Anantanarayanan.Raman@csiro.au rizes what is currently known in the induction of galls, simultaneously pointing to the many gaping holes in that knowledge and the areas that need to be focused upon.

Galls induced by insects (hereafter 'galls') exemplify defined plant growth ${ }^{12-14}$. Plant-growth regulators (PGRs) were implicated as the key. Nysterakis ${ }^{15,16}$ demonstrated auxins in the salivary extracts of gall-inducing Daktulosphaira vitifoliae (Phylloxeridae) on Vitis vinifera (Vitaceae) and leaf curl-inducing Brachycaudus helichrysi (Aphididae) on Prunus domestica var. domestica (Rosaceae) by testing with the oat-coleoptile and vine-tendrilspin tests, popular in the 1940s. The inhibitory and hypertrophic effects on plants with salivary-extract injections were clarified as due to variations in auxin levels ${ }^{17,18}$. In the $D$. vitifoliae $-V$. vinifera gall system, Nysterakis ${ }^{17,19}$ related the auxins detected in the saliva of $D$. vitifoliae to auxin precursors in $V$. vinifera. Boysen-Jensen ${ }^{20}$ determined that auxins regulate growth in the galls induced by Mikiola fagi (Cecidomyiidae) on Fagus sylvatica (Fagaceae). In the next two decades, Guiscarfé-Arillaga ${ }^{21}$, Beck $^{22}$, Nolte ${ }^{23}$, Leatherdale ${ }^{24}$ and Schäller ${ }^{25}$ - to name a few - obtained 'swellings' on plants by injecting measured quantities of indole-acetic acid (IAA). Such artificially induced swellings were true plant growths, but they differed from the naturally induced galls because the former lacked a definite shape and internal tissue differentiation. Bioassay of whole-body extracts (WBEs) of insects was a popular method used in implicating IAA $^{26,27}$. Hori ${ }^{28,29}$ confirmed auxin-like compounds in non-gall-inducing, plant-feeding Miridae, Pentatomidae and Coreidae (Hemiptera) using the WBE method in the 1970s.

Although only indirectly relevant, it would be pertinent to recall the 'tumour-inducing principle' (TiP) in Agrobacterium (Rhizobiaceae)-induced tumours on plants proposed by Braun ${ }^{30}$ (Rockefeller University, USA) in the 1950s. The TiP got explained as the 'Ti-plasmid' edited by an endonuclease in the 1980s. However, many stark differences differentiate an Agrobacterium-induced tumour from a gall ${ }^{31}$.

When much was spoken about the role of IAA and other plant hormones in galls, Anders ${ }^{32}$ detected lysine, histidine and tryptophan in higher levels, and glutamic acid and valine in lower levels in the salivary secretions of $D$. vitifoliae. He generated knotty swellings ('nodosities') on 
$V$. vinifera roots cultured in solutions with measured quantities of the specified amino acids. Because the generated swellings were morphologically similar to galls induced by $D$. vitifoliae on the roots of $V$. vinifera, Anders implicated these amino acids as the gall-inducing chemicals; alternatively, they could be the precursors of the gall-inducing chemical. Between 1958 and 1961, Anders published several articles reinforcing the role of amino acids in gall induction. However, this was challenged a decade later by Miles ${ }^{33}$ (Adelaide University, Australia).

\section{Galls are more than entomological and botanical novelties}

A gall is the product of a natural, tight relationship between specific insects and plants. It is a near-perfect, exquisite expression on a plant in response to insect action $^{34}$ (Figure 1). The response pattern of plants to gallinducing insects varies: some plant taxa are susceptible and an equal number are resistant because of the levels and types of proteins they include ${ }^{35,36}$. An understanding

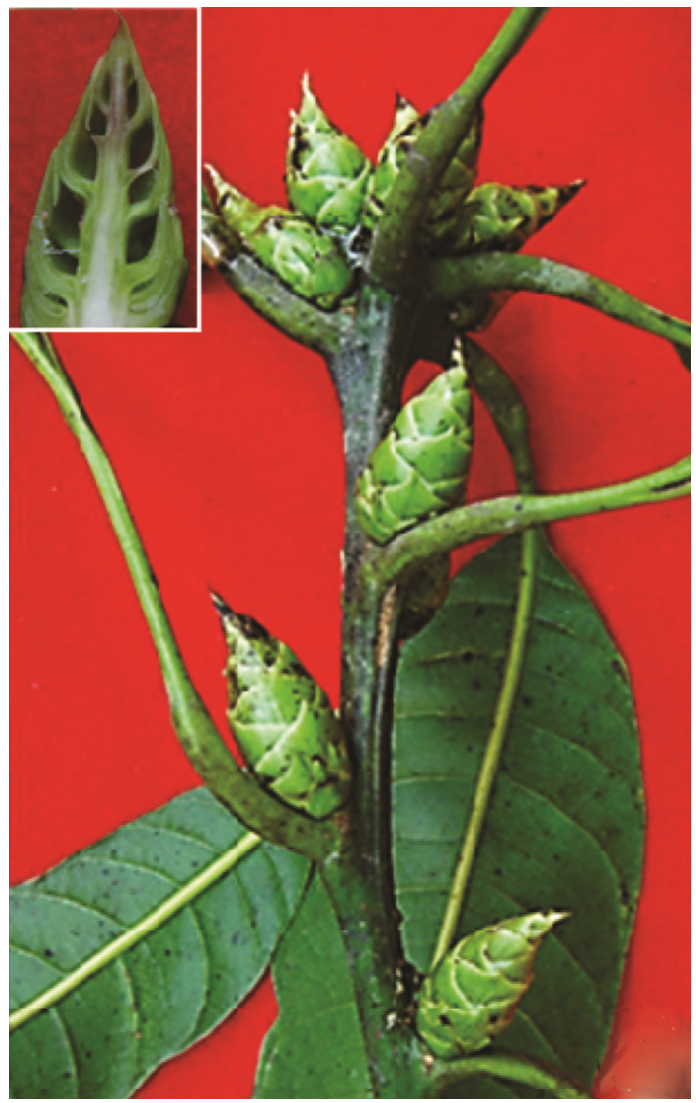

Figure 1. Fir cone-like galls induced by Apsylla cistellata (Hemiptera: Psylloidea: Aphalaridae: Rhinocolinae) on the vegetative axillary meristems of Mangifera indica (Anacardiaceae). (Inset) Vertical sectional view of the gall showing nymphal chambers. For the biology of A. cistellata and gall development, see Raman et al. ${ }^{134}$. For distribution details, see Sharma and Raman ${ }^{68}$, Burckhardt et al. ${ }^{135}$. that a gall is the result of insect action is vital, because other plant abnormalities such as witches' brooms, fasciations, crinkles, folds and puckerings - either vectored by insects or induced by microbes - are not. In a gall, the inducing insect lives as a parasite inflicting minimal alterations to the physiology of the host and not killing it. Küster ${ }^{34}$ constructively aligned the explanation of galls on the proposition made earlier by Friedrich Thomas ${ }^{37, \text { p. } 513 \text { : }}$

'Ein Cecidium nenne ... gegen den erfahrenen Reiz.'.

A gall - cecidium - is a developmental deviation of the plant induced by a parasite. The word 'development' means an active process. When a leaf is either consumed or mined by a caterpillar, a gall does not manifest. To establish a gall, active growth in the part of a plant occurs in response to the stimulus from the parasitic organism.

A gall is a phenotypic expression that arises because of perturbation in normal plant growth initiated and stimulated by the insect. In the more-evolved insect orders, e.g. Diptera, an individual neonate induces a gall. In the lessevolved orders, e.g. Thysanoptera and Eriophyoidea, in contrast, a population arising from a gravid female contributes to gall development, although initiation is by the feeding action of the gravid female ${ }^{38}$. The group gallestablishment behaviour, as in the Thysanoptera and Eriophyoidea, occurs in some of the gall-inducing Sternorrhyncha, e.g. Adelgidae ${ }^{39}$. What clarifies a gallirrespective of the inducing insect belonging to a moreor less-evolved order - is the insect's dependence on the plant for nutrition. Therefore, establishment of the tissue of nutrition in the gall, redirection of different primary metabolites and minerals to that tissue, and completion of most segments of the lifecycle of the inducing insect within the gall are crucial in defining it ${ }^{40}$.

Development of a gall can be generalized into the following stages: (i) initiation, (ii) triggering of new differentiation pathways, including establishment of a special tissue for nutrition, with a concurrent inhibition of the normal development, (iii) growth and (iv) ageing and senescence ${ }^{41,42}$. This explanation has been verified in many galls on various dicotyledons induced by different insect taxa ${ }^{13,43-45}$. Although each gall is unique in shape, either a radial or bilateral symmetry in external morphology manifests, an aspect that is strongly deficient in microbe-induced tumours ${ }^{46,47}$. The nematode-induced root knots (e.g. Meloidogyne, Heteroderidae) are amorphous, similar to microbe-induced tumours in external morphology, but differ from the latter because they include 'giant-nurse cells' nourishing the nematode ${ }^{48}$. These cells are structurally and functionally similar to nutritive cells in galls. 
To comprehensively understand how galls are induced, the critical element will be to examine the physiology of the first two stages: initiation and triggering of new differentiation pathways, which involve the formation of secondary messengers in response to the signals perceived by the plant because of insect action. The PGRs are produced during either the late second or the third stage of gall development. Production of endogenously produced PGRs at a greater intensity than normal - as in galls requires a trigger, highly likely, a high-molecular weight protein. An interplay of abscisic acid and ethylene along with auxins and cytokinins occurs in senescing galls, similar to the physiology of senescing fruits ${ }^{49}$.

\section{Host-plant relations of gall-inducing insects}

Not all plant-feeding insects induce galls, but only species belonging to certain families of the Eriophyoidea (Acari) and Thysanoptera, Hemiptera, Diptera, Lepidoptera, Coleoptera and Hymenoptera (Insecta). Among these, the species of Hemiptera, Diptera, Lepidoptera and Coleoptera (Curculionidae) induce galls by the feeding action of their immature stages, whereas in Hymenoptera, gall initiation starts with the ovipositing female inserting her ovipositor into the plant organ, concurrently discharging accessory-gland secretions $^{50,51}$. Gall induction in certain tribes of the Cecidomyiidae - Asphondyliini, Porricondylini and Lasiopterini - occurs via insertion of the ovipositor $^{52}$ along with the introduction of fungal spores ${ }^{53}$. Such a gall-inducing behaviour among Cecidomyiidae is odd.

Gall-inducing insects exemplify a sophisticated level of phytophagy. Well-defined galls are induced on specific species of plants by specific species of insects ${ }^{54,55}$. This specialist behaviour leads to considering gall-inducing insects as 'excellent plant taxonomists' ${ }^{56}$. The recent resolution reached in the context of Ocnothrips cochinchinensis (Phlaeothripidae) that induces large sac-like galls on Getonia floribunda (Calycopteris floribunda, Combretaceae) in peninsular India ${ }^{57}$ illustrates this point. In a majority of gall-inducing insects, specialization extends to specific organs and sites ${ }^{58}$. Exceptions exist, however. For instance, Thilakothrips babuli (Phlaeothripidae) induces rosette galls on both leaflets and florets of Vachellia leucophloea (Fabaceae: Mimosoideae) in southern India ${ }^{59}$. Quadristichus erythrinae (Eulophidae) is claimed to induce gall-like abnormalities on the leaves and flowers of more than six species of Erythrina (Fabaceae $)^{58}$. Similarly, Leptocybe invasa (Eulophidae) is indicated as the inducer of gall-like abnormalities on the petioles, leaves and flowers of about 30 species and subspecific variants of Eucalyptus (Myrtaceae) ${ }^{60}$. Quadristichus erythrinae and L. invasa are confirmed oligophages, and oligophagy is less known among established gallinducing taxa ${ }^{61}$. Prodiplosis longifila (Diptera: Cecidomyiidae), recorded as the inducer of rosette galls ${ }^{62}$ on the shoot terminals of Jatropha clavuligera (Euphorbiaceae) in South-Central America, is also known to occur on several unrelated plants both as a gall-inducing taxon and not a gall-inducing taxon ${ }^{55}$. However, host-specificity tests of infested and uninfested shoots of the Bolivian populations of $J$. clavuligera and a few allied and co-occurring species of Jatropha, made in 2017, have clarified that the populations of $P$. longifila living on $J$. clavuligera are a host-specific, cryptic species of the $P$. longifila species complex ${ }^{63}$. Therefore, the question is whether the anomalies induced by $Q$. erythrinae and L. invasa are true galls? That other biological agents, possibly a fungus, induce amorphous growth on Erythrina and Eucalyptus, subsequently infested by the respective Eulophidae, is a strong possibility.

How and why most of the gall-inducing insects remain tied to specific plants is a mystery. Possibly gall induction requires specific molecular signals that can be triggered only by a particular species of insect endowed with specific proteins. One early explanation was that the gallinducing Taxomyia taxi (Cecidomyiidae) selectively exploits Taxus baccata (Taxaceae) for sterols necessary for the larvae to become adults ${ }^{64}$. Specific mono- and di-glycerides were detected in young, uninfested leaves of Eucalyptus macrorhyncha (Myrtaceae) in CentralWest New South Wales, Australia, that hosts an unnamed gall-inducing species of Glycaspis (Synglycaspis) (Aphalaridae $)^{65}$. The natural habitat of E. macrorhyncha includes co-occurring populations of Eucalyptus rossii and Eucalyptus dives. Botanists (e.g. ref. 66) treat these three Eucalyptus taxa under the same group: 'Eucalyptus subgen. Eucalyptus + Primitiva'. The unnamed, pouch gall-inducing species of Glycaspis (Synglycaspis) never occurs on either $E$. rossii or E. dives. Significant levels of sitosterol, ergosterol and stigmasterol were detected in young leaves of E. macrorhyncha susceptible to gall induction by this species of Glycaspis (Synglycaspis). Moreover, sitosterol and three other undetermined sterols of molecular weights 354,382 and $440 \mathrm{~g} \mathrm{~mol}^{-1}$ were present maximally only in young leaves of E. macrorhyncha, but absent in $E$. dives and $E$. rossii leaves of comparable age. The unique $440 \mathrm{~g} \mathrm{~mol}^{-1}$ sterol was clinched as the principal factor in the choice of E. macrorhyncha by the gall-inducing species of $G$. (Synglycaspis), because of its high levels in the young, gall-susceptible leaves of E. macrorhyncha (Table 1$)^{67}$, explaining the choice of E. macrorhyncha by the species of $G$. (Synglycaspis $)^{68}$ in a community of E. macrorhyncha, E. dives and E. rossii. This study ${ }^{67}$ reinforced the explanation ${ }^{64}$ made in the 1980s that gall-inducing insects choose specific plants to meet their sterol needs.

\section{The earliest recognizable element in a gall - the metaplasied cell}

Gall initiation becomes apparent in the first $24 \mathrm{~h}$ of attack of the plant by the insect (ref. 69, figure 30). In the Fagus 
Table 1. Evaluation of $\delta^{13} \mathrm{C}$ and $\delta^{15} \mathrm{~N}$ signatures and total non-structural carbohydrates (TNCs) in different plant stages and tissues (including galls and non-gall-bearing parts) from Parthenium hysterophorus infested by Epiblema strenuana*

\begin{tabular}{|c|c|c|c|c|c|c|c|c|c|}
\hline \multirow[b]{2}{*}{ Source of variation } & \multicolumn{3}{|c|}{$\begin{array}{c}\text { Carbon isotope ratios } \\
\left(\Delta\left(\delta^{13} \mathrm{C} \text { air }-\delta^{13} \mathrm{C} \text { sample }\right)\right)\end{array}$} & \multicolumn{3}{|c|}{$\begin{array}{c}\text { Nitrogen isotope ratios } \\
\left(\Delta\left(\delta^{15} \mathrm{~N} \text { air }-\delta^{15} \mathrm{~N} \text { sample }\right)\right)\end{array}$} & \multicolumn{3}{|c|}{ TNC concentration } \\
\hline & d.f. & $F$ & $P$-value & d.f. & $F$ & $P$-value & d.f. & $F$ & $P$-value \\
\hline Plant stage & 2 & 94.040 & $<0.001$ & 2 & 11.11 & $<0.001$ & 2 & 2.22 & ns \\
\hline Plant part & 4 & 114.60 & $<0.001$ & 4 & 205.60 & $<0.001$ & 4 & 0.28 & ns \\
\hline Plant stage versus plant part & 8 & 8.07 & $<0.001$ & 8 & 39.29 & $<0.001$ & 8 & 0.31 & ns \\
\hline Residual & 119 & & & 55 & & & 70 & & \\
\hline
\end{tabular}

ns, Not significant. *Source: Raman et al. ${ }^{101}$.

sylvatica (Fagaceae) - Hartigiola annulipes (Cecidomyiidae) gall system, dynamic changes occur at the site attacked by the neonate $H$. annulipes in less than $24 \mathrm{~h}^{70}$ (Figure $2 a-c$ ). Similar changes occur on tender leaves of susceptible varieties of $V$. vitifera during attack by neonate nymphs of $D$. vitifoliae in less than $24 \mathrm{~h}$ (ref. 71).

Gall initiation commences from the moment the tip of the mandible (e.g. Cecidomyiidae) or the stylet (e.g. Sternorrhyncha) punctures a plant cell. In the gall-inducing Hymenoptera, in contrast, gall initiation occurs with the insertion of the ovipositor ${ }^{50,51,72-74}$. On coming in contact with the mandible (or the stylet) or the ovipositor tip, isolation and insulation of one cell in the host organ (e.g. leaf) occurs with the plasma membrane withdrawing from the cell wall, snapping of plasmodesmata, followed by callosic blocking of pit fields ${ }^{75}$. In the next $12-24 \mathrm{~h}$, the isolated and insulated cell turns metaplasied $33,44,69,76,77$.

Küster $^{78}$ first recognized metaplasied cells in galls. Metaplasia was previously explained in early-stage human cancer by Rudolf Virchow in 1884. According to Küster $^{78, p . ~} 237$

'Metaplasie spielt in der pathologischen Histologie ... Bindengewebe in Fettgewwebe sich umwandelt.'

Metaplasia plays a more serious role in the pathological histology of plants than that of animals and humans. We see different kinds of metaplasied cells forming the basis for various important plant-pathological processes. Of course, such a transformation (i.e. from normal cell to metaplasied cell) is possible only among closely related tissue meristems, especially among the binding tissues (e.g. parenchyma). Nevertheless, in metaplasia, the original character of the converted cells can be thoroughly unrecognizable - for example, a binding tissue (e.g. cortical parenchyma) transforms into fat (i.e. lipid)-including (i.e. storage) tissue.

Virchow explained metapalasia as the replacement of one differentiated cell type by another differentiated cell type, normally absent in that tissue, and cancer arises by the activation of 'dormant cells' (stem cells, today) via irritation $^{79}$. Presently, the terms 'dedifferentiation' and 'transdifferentiation' have replaced metaplasia in plant ${ }^{80}$ and animal physiology ${ }^{81}$ respectively.
The cell injured by the tip of either the pointed mandibular tooth as in Cecidomyiidae ${ }^{82}$ or the pointed, needlelike terebra of the ovipositor as in Cynipidae ${ }^{83}$ loses its polarity, turns metaplasied, followed by rapid changes in the quality and quantity of subcellular inclusions. The establishment of a metaplasied cell, however, varies with the nature of the influencing mechanism of the inducing insect and is regulated by the nature of either the mouth parts or the ovipositor of the involved insect, as the case would be. One distinct feature of the metaplasied cell is the asymmetrical distribution of proteins either in or on the plasma membrane ${ }^{84}$. These subcellular modifications enable the host plants to adjust and align their continued growth. Following the establishment of a metaplasied cell, sequel to wounding and irritation caused by insect action, the chemical(s) discharged from the saliva or the accessory glands trigger cell-division activity around $i^{14}$. Details of the involved chemical(s) are presently unknown: high-molecular weight proteins ${ }^{85}$, bruchins ${ }^{86}$, mitogenic lipids ${ }^{87}$ ? The establishment of metaplasied cell(s) at the prospective gall site is pivotal in gall initiation.

\section{The nutritive tissue}

Several subcellular modifications, reflecting the physiology of the involved cell, follow immediately. I will use examples of D. vitifoliae - Vitis cv. 3309 Couderc $(V \text {. riparia } \times V \text {. rupestris cv. C-3309) })^{71}$ and Aceria lycopersici (Eriophyidae)-Solanum dulcamara (Solanaceae $)^{88}$ to illustrate the less than $24 \mathrm{~h}$ changes in the susceptible plant organ, a leaf.

The tips of $60-65 \mu \mathrm{m}$ long stylets of the neonate nymphs of $D$. vitifoliae can only reach the fifth-sixth layer mesophyll cells. In $3-6 \mathrm{~h}$, the cell including the stylet tip enlarges at least twice its normal size, concurrently presenting a modified subcellular structure (Figure $3 a$ ), similar to the changes that occur in early-stage human cancer cells, except cell-wall modifications. In the next $24 \mathrm{~h}$, the mesophyll-parenchyma cells lining the stylet path present modified subcellular profiles (Figure $3 \mathrm{~b}$ ). Vitis cv. 3309 Couderc leaf under the feeding pressure of D. vitifoliae develops a nutritive tissue in $48 \mathrm{~h}$. Such 


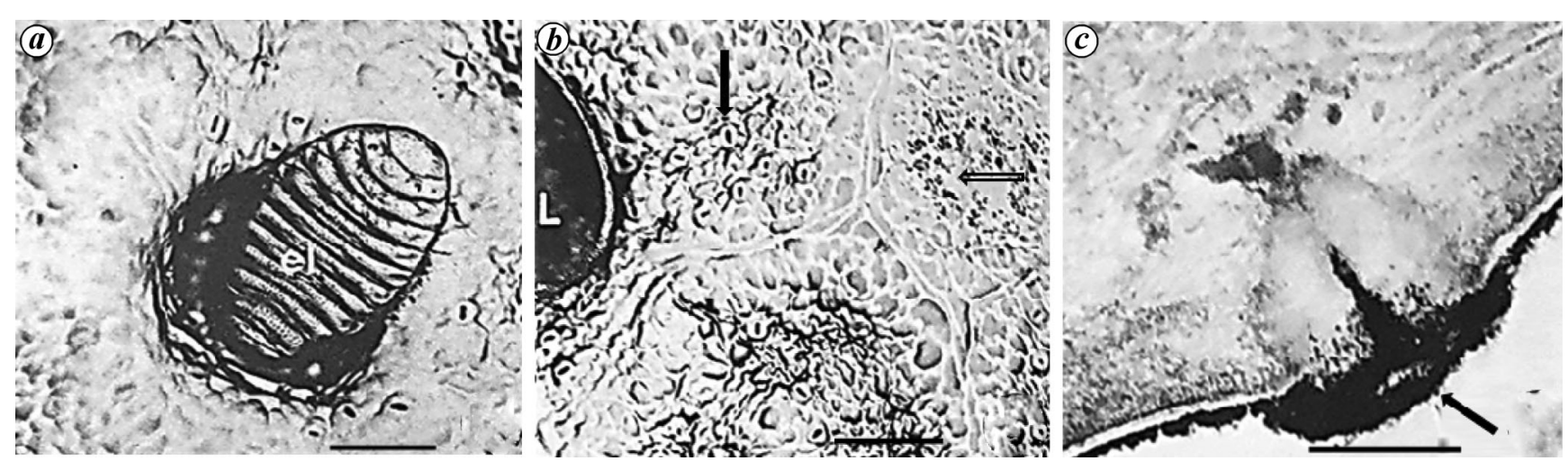

Figure 2. Gall initiation $(<24 \mathrm{~h})$ on the leaves of Fagus sylvatica by neonate larvae of Hartigiola annulipes. a, Neonate H. annulipes larva (el) settling on a leaf of $F$. sylvatica. Note the edges around the larva showing early signs of overarching growth (scale bar - $100 \mu \mathrm{m})$. $\boldsymbol{b}$, Paired feeding punctures inflicted by $H$. annulipes (unfilled arrow), stomata (filled arrow; scale bar $-100 \mu \mathrm{m}$ ). $c$, Sectional view of a feeding puncture (EM) (arrow - callose; scale bar $-0.5 \mu \mathrm{m}$ ). (Source: Rohfritsch ${ }^{70}$, with permission from O. Rohfritsch.)
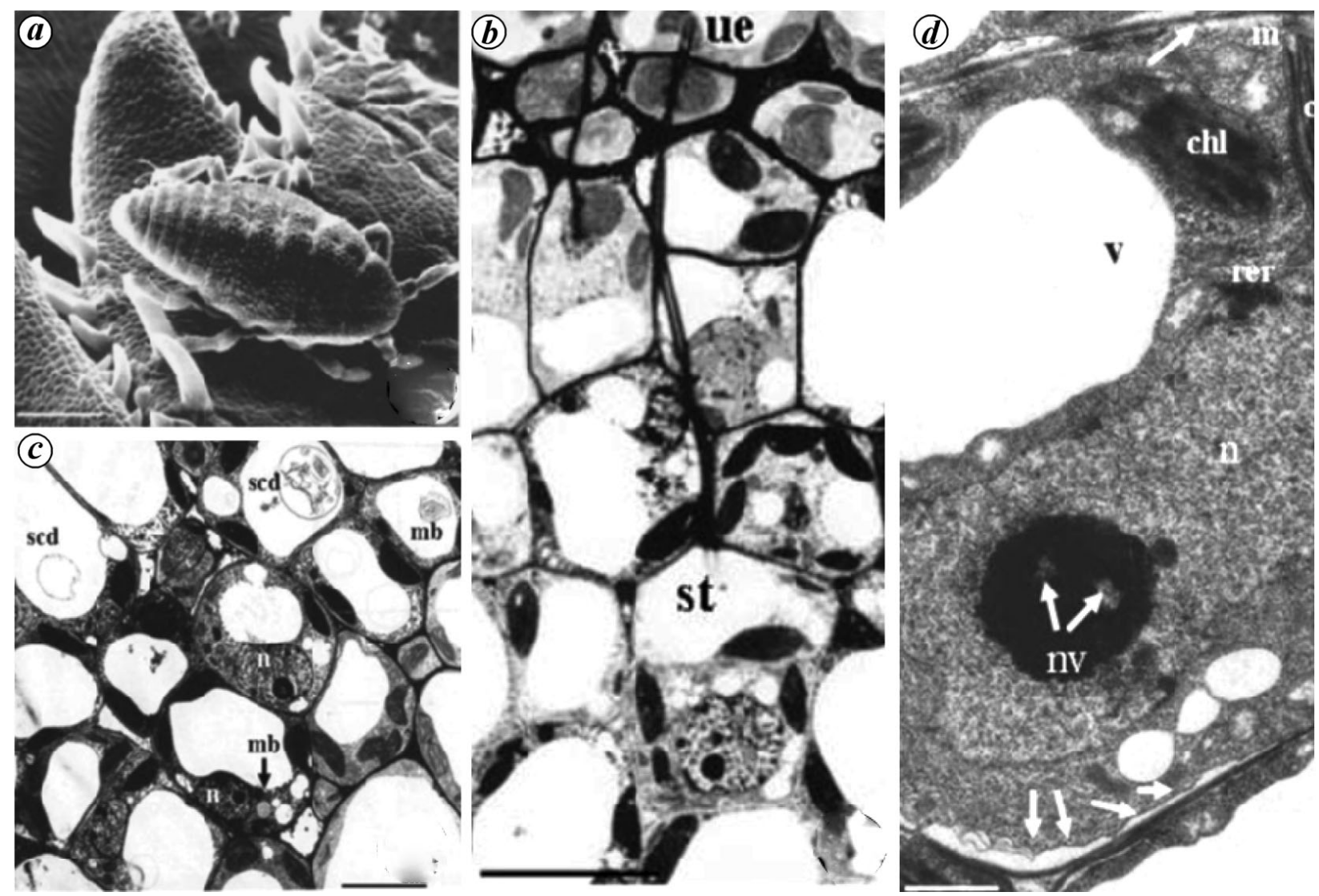

Figure 3. Less than $24 \mathrm{~h}$ in Daktulosphaira vitifoliae interaction with Vitis vinifera cv. 3309 Couderc leaf. a, Neonate nymph of D. vitifoliae on Vitis leaf $(1 \mathrm{~h}$; scale bar $-100 \mu \mathrm{m})$. b. Target parenchyma cell including the stylet tip (st) activated and characterized by intense cytoplasm, enlarged nuclei and numerous small vacuoles; the parenchyma cells along the stylet path are also activated, developing into the nutritive tissue which includes abundant chloroplasts (3-6 h) (ue, upper epidermis; Scale bar $-100 \mu \mathrm{m}) . c$, Parenchyma cells, slightly away from the developing nutritive tissue, include enlarged nuclei (n), hyaline cytoplasm, and from one to a few centrally placed large vacuoles with many small and large exhausted multi-vesicular bodies ( $\mathrm{mb}$ ) and subcellular debris (scd); the multivesicular bodies in the developing nutritive cells appear normal and active (arrow; 3-6 h; scale bar $-100 \mu \mathrm{m}$ ). $\boldsymbol{d}$, A nutritive cell with enlarged and irregularly-shaped nuclei (n) and enlarged nucleoli; the nuclei include electron-dense chromatin material and interchromatin granules, whereas the nucleoli are vacuolated (nv); membranes of the nuclear envelope are separated and bear patches of electron-dense condensations; the plasma membrane is unevenly retracted (arrows) from the cell wall; especially at the retraction points, lomasomes occur in the periplasmic space; cytoplasm is dense and includes many small, but scattered vacuoles (v); strands of rough endoplasmic reticulum (rer) occur scattered throughout the cytoplasm; the mitochondria (m) distributed along the plasma membrane appear normal and are numerous, whereas those either between the nucleus and vacuoles or between two adjacent chloroplasts include vesiculated cristae and empty central spaces; chloroplasts (chl) are not hypertrophied, but the granal stacks are numerous and compressed; the thylakoids are condensed with their membranes dilated, sequel to granal compression; chloroplasts include neither plastoglobuli nor starch (24 h response; scale bar $-1 \mu \mathrm{m}$ ). (Source: Raman et al. ${ }^{71}$.) 
tissue includes hypertrophied cells and nuclei, more-thanusual numbers of mitochondria, and other modified cell organelles. This tissue includes high levels of starch and lipids, but low levels of phenolic inclusions (Figure $3 c$ and $d$ ).

At this earliest 'recognizable' stage of gall induction, the nucleus in the metaplasied cell remains spherical and unlobed, but will be strikingly different from the nuclei in normal cells in the same organ by its large size, greatly dispersed heterochromatin and large nucleolus. Many subcellular changes occur concurrently. The endoplasmic reticulum expresses as myelin figures indicating oxidative stress ${ }^{89}$. The Golgi bodies get intensely modified reflecting alterations in the pathways in lipid-protein metabolism and subcellular transport. Mitochondria mostly remain unaltered, indicating no major alteration in the respiratory activity. Variously modified plastids occur reflecting stress and altered photosynthesis ${ }^{90}$. This modified tissue will include elevated levels of primary metabolites, further to an intense phosphatase activity reinforcing greater inorganic phosphate utilization ${ }^{91}$. Starch usually occurs in non-hydrolysable form in cells away from the site of feeding by the insect; lipids, on the other hand, occur in cells close to the insect ${ }^{92}$. In Cynipidae-induced galls, lipids occur as di- and triacylglycerides $^{14}$. The contrasting distribution patterns of carbohydrates and lipids in the nutritive tissue are an established expression of stress-neutralization effort by the plant ${ }^{93}$, because of the production of superoxide radicals affecting various cell and tissue functions ${ }^{94}$.

The less than $24 \mathrm{~h}$ changes that occur in the leaf cells of susceptible varieties of $S$. dulcamara punctured by the chelicerae of $A$. lycopersici include vacuolar alkalinization followed by alteration in DNA levels associated with chitosan build-up ${ }^{95}$, illustrating the changes influenced by signal perception and transduction. This action triggers the host plant cell to turn metaplasied, communicating with the neighbouring cells via signal transduction. A nutritive tissue gets established in the next 3-4 h, on which individuals of $A$. lycopersici feed. These changes never manifest in the varieties of $S$. dulcamara resistant to $A$. lycopersici. In the incompatible (resistant) reactions between A. lycopersici and $S$. dulcamara, a rapid spread of subcellular damage from the punctured cell to those in the neighbourhood manifests as cell necrosis, expressing externally as tissue lesions. This hypersensitive reaction in resistant varieties of $S$. dulcamara impedes further feeding by $A$. lycopersici, followed by their death ${ }^{96}$.

Establishment of the nutritive tissue in galls reinforces the nutrition hypothesis, underpinning its ecological relevance in gall induction ${ }^{76,97,98}$. The structure and design of nutritive tissue in galls induced by different insect groups is generalizable, although the specific nature of location, distribution and orientation varies with insect groups ${ }^{93}$. Such a variation arises because of the nature of the mouth parts of the inducing insect(s) and their respective feeding behaviour(s). For example, in galls induced by hemipteroids with sucking behaviour, nutritive tissue differentiates at varied depths on the same plant organ (e.g. a leaf). In galls induced by Phlaeothripidae, the nutritive tissue differentiates immediately below the epidermis, because of the short length and asymmetricity of mouth parts ${ }^{99}$. In contrast, in galls induced by Sternorrhyncha that bear relatively long and slender stylets, the nutritive tissue develops at 5-10 layers depth in the mesophyll ${ }^{100}$. The location of the nutritive tissue in the plant organ is directly related to the lengths of stylets of the feeding Sternorrhyncha ${ }^{45,101}$.

Feeding action - physical injury and irritation, chemical action by the salivary secretions - of the inducing insect ensures the active status of the nutritive tissue. When the larva stops feeding, the nutritive tissue loses its dynamic profile and gets replaced by inactive parenchyma and occasionally by lignified tissue (e.g. sclereids) ${ }^{14,43,102}$. When the larva is either removed or killed, the distribution of carbohydrates and lipids in the non-functional nutritive tissue rapidly reverses ${ }^{93}$. Accumulation of other metabolic products, such as minerals, is known ${ }^{103,104}$, but those details would be irrelevant here.

That a gall is a nutrient sink was first shown in the M. fagi-F. sylvatica gall system by Kirst and Rapp ${ }^{105}$ (Darmstadt, Germany) in the 1970s. Total non-structural carbohydrates (TNCs) and carbon-nitrogen isotope ratios were measured in tissues of galls, gall-proximal, galldistal and non-gall-bearing stems of identical age of Parthenium hysterophorus (Asteraceae) induced by Epiblema strenuana (Curculionidae) ${ }^{106}$. The E. strenuana larvae drain nutrients and energy, stress the shoot tissues of $P$. hysterophrous by intercepting normal-nutrient transport. The $\delta^{13} \mathrm{C}$ and $\delta^{15} \mathrm{~N}$ values in galls were significantly different from those in stem segments proximal and distal to the galls, although the TNC levels were insignificant regardless of plant age (Figure 4 and Table 2 ). The stem distal to the gall functioned more efficiently as a nodal channel than the stem proximal to the gall, especially in the translocation of nitrogenous nutrients, affirming that a gall is a nutrient sink. This is due to the injury inflicted by feeding action of the insect, and the plant responds by pumping nutrients to the gall site primarily to repair the injury. The insect utilizes the redirected nutrients to its advantage.

\section{Gall growth}

Bioassays of galls induced at the base of the young needles of Pinus edulis (Pinaceae) by Janetiella coloradensis (Cecidomyiidae) revealed that the galls included about 20 times more of auxin activity and gibberellin-like substance activity. The highest levels of both auxin and gibberellin-like substance were apparent during the rapid gall growth stage ${ }^{107}$. Curiously, only traces of substances 

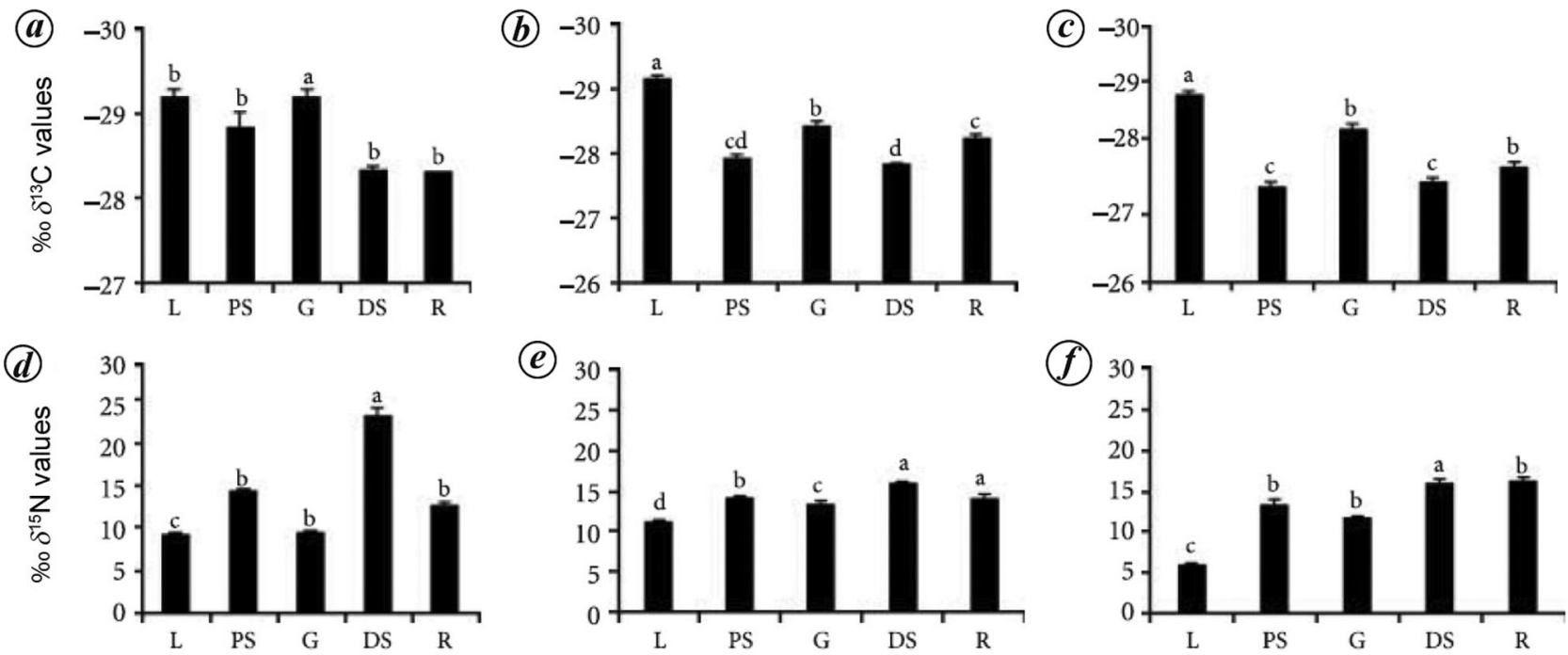

(e)

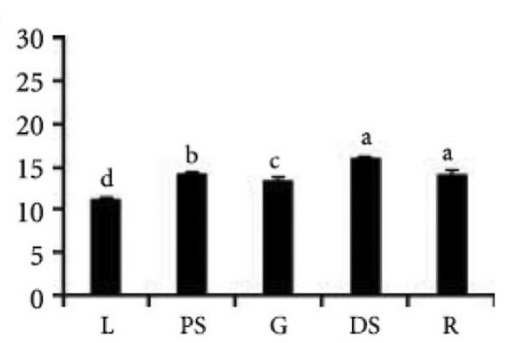

(t) 3
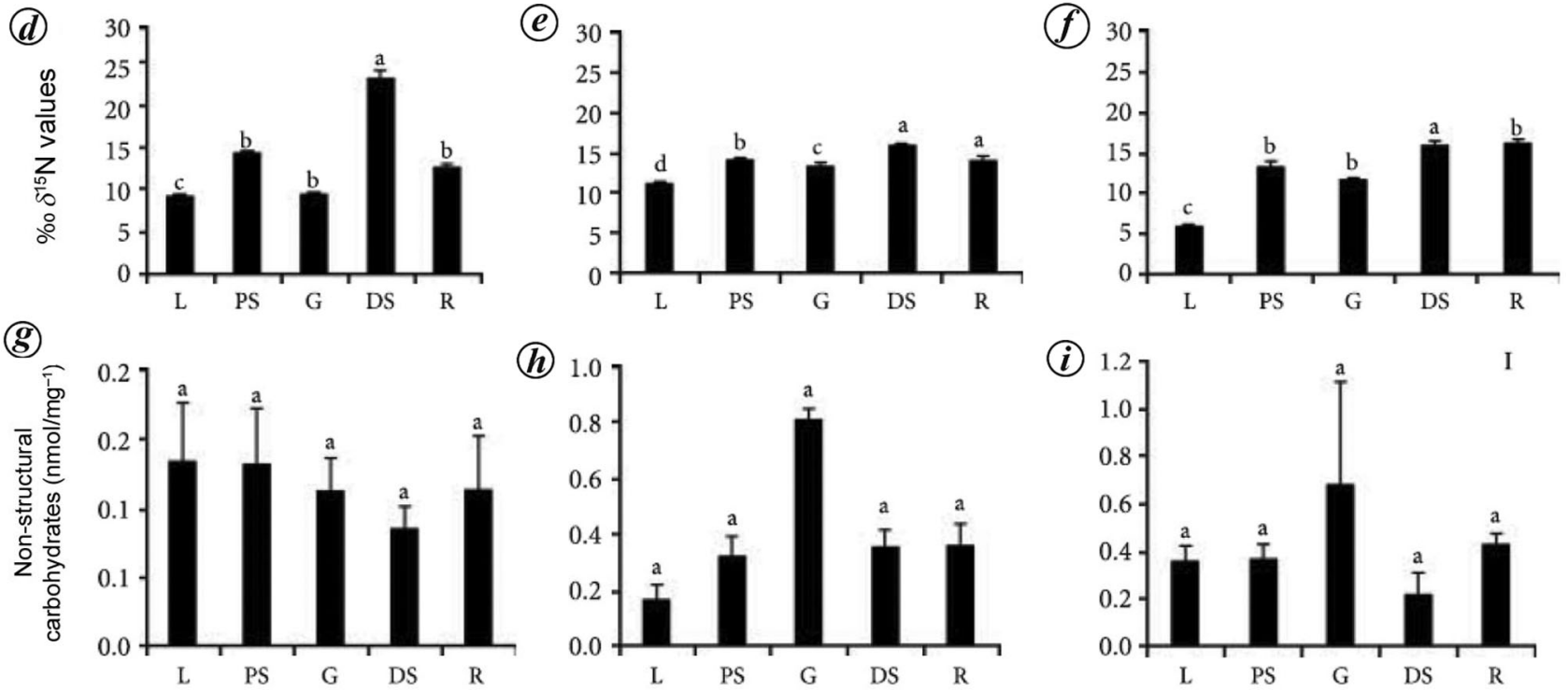

Figure 4. Mean values ( $+\mathrm{SE}$ of mean) of $\delta^{13} \mathrm{C}$ and $\delta^{15} \mathrm{~N}$, and levels of total non-structural carbohydrate (TNC) from the leaf (L), proximal stem (PS), gall (G), distal stem (DS) and root (R) in different developmental stages of Parthenium hysterophorus. Same letters indicate that means are not statistically different (Tukey's HSD test, $P<0.05)$. $(\boldsymbol{a}-\boldsymbol{c})$ Carbon values $\left(\delta^{13} \mathrm{C}, \%\right.$ o from rosette $(\boldsymbol{a})$, preflowering $(\boldsymbol{b})$ and flowering $(\boldsymbol{c})$ stages. $(\boldsymbol{d}-\boldsymbol{f})$ Nitrogen values $\left(\delta^{15} \mathrm{~N}, \%\right.$ o) from rosette $(\boldsymbol{d})$, preflowering $(\boldsymbol{e})$ and flowering $(\boldsymbol{f})$ stages. $(\boldsymbol{g}-\boldsymbol{i})$ TNC levels from rosette $(\boldsymbol{g})$, preflowering $(\boldsymbol{h})$ and flowering $(\boldsymbol{i})$ stages. Source: Raman et al. ${ }^{106}$.

with gibberellin-like activity were detected and there were no auxins at detectable levels in the extracts of J. coloradensis ${ }^{107}$. Byers et al. ${ }^{107}$ extrapolated this finding that the auxins are of plant source and insect action stimulates their activation. In contrast, in an unnamed species of Pontania (Tenthredinidae)-Salix japonica (Salicaceae) gall system ${ }^{108}$, IAA has been detected in the larval saliva, metabolized from tryptophan via deamination and decarboxylation. Transcript levels of auxin- and cytokinin-responsive genes were higher in gall-bearing than in non-gall-bearing plant organs, indicating that the insect action activates the genes responsible for this action. Abnormally high levels of $t$-zeatin riboside in Pontania galls on $S$. japonica indicate that Pontania could synthesize cytokinins as well as IAA. Gene profiles indicate high levels of auxin and cytokinin activity in galls ${ }^{108}$. Yamaguchi et al. ${ }^{108}$ clarify that the two undetermined adenine derivatives identified by McCalla et al. ${ }^{109}$ in the 1960 s are in fact the ' $t$-zeatin riboside' and 'isopentenyladenosine', signal molecules of cytokinin biosynthesis in plants. This is an elegant explanation of stage- 3 in gall development. Using gas chromatography coupled with mass spectrometry (GC-MS), high levels of IAA have been demonstrated in the larvae of Eurosta solidaginis (Tephritidae) $^{110}$ and Gnorimoschema gallaesolidaginis (Gelechiidae $)^{111}$ respectively, both inducing galls on the stems of Solidago altissima. Collectively, the studies made in recent years, using sophisticated analytical equipment and those made between the 1940s and 1980s using less sophisticated methods suggest the possibility that the inducing insect larvae include precursors of IAA and cytokinins, which get introduced into the plant tissues through their salivary or accessory-gland secretions.

\section{Senescing galls}

The physiology of galls on maturation, i.e. when the inducing insect ceases to feed and refrains from stimulating the gall to grow is broadly similar to the physiology of normally ripening and senescing fruits ${ }^{112}$. However, what needs to be factored here is that the proportions of production, transport and storage of various primary and secondary metabolites vary with the insect and plant 
REVIEW ARTICLE

Table 2. Sterols (mol\%) in uninfested and gall-bearing leaves of Eucalyptus macrorhyncha and comparable leaves of Eucalyptus rossii and Eucalyptus dives*

\begin{tabular}{|c|c|c|c|c|c|c|c|c|c|c|c|}
\hline \multirow{3}{*}{$\begin{array}{l}\text { Sterol } \\
\text { molecular weight }\end{array}$} & \multicolumn{7}{|c|}{ E. macrorhyncha-Synglycaspis sp. system (sterols in mol\%) } & \multirow{2}{*}{\multicolumn{2}{|c|}{$\begin{array}{c}\begin{array}{c}\text { E. rossii } \\
\text { (sterols in } \mathrm{mol} \%)\end{array} \\
0\end{array}$}} & \multirow{2}{*}{\multicolumn{2}{|c|}{$\begin{array}{c}\begin{array}{c}\text { E. dives } \\
\text { (sterols in mol\%) }\end{array} \\
0\end{array}$}} \\
\hline & \multicolumn{2}{|c|}{0} & \multicolumn{5}{|c|}{ I } & & & & \\
\hline & $\mathrm{Y}$ & M & $1^{\prime}$ & $2^{\prime}$ & $3^{\prime}$ & $4^{\prime}$ & $5^{\prime}$ & $\mathrm{Y}$ & M & Y & M \\
\hline 326.4 & 0.02 & 0.03 & 0.02 & 0.02 & 0.03 & 0.03 & 0.023 & 0.02 & 0.01 & 0.03 & 0.02 \\
\hline 354.1 & 0.08 & 0.11 & 0.07 & 0.07 & 0.08 & 0.07 & 0.06 & 0.14 & 0.08 & 0.16 & 0.13 \\
\hline 382.1 & 0.13 & 0.2 & 0.14 & 0.16 & 0.17 & 0.18 & 0.12 & 0.40 & 0.32 & 0.27 & 0.37 \\
\hline 396.3 & 0.01 & 0.02 & 0.01 & 0.01 & 0.01 & 0.01 & 0.01 & 0.01 & 0.01 & 0.00 & 0.01 \\
\hline 410.2 & 0.05 & 0.25 & 0.06 & 0.12 & 0.12 & 0.18 & 0.13 & 0.08 & 0.13 & 0.02 & 0.02 \\
\hline 412.4 & 0.05 & 0.05 & 0.05 & 0.05 & 0.05 & 0.05 & 0.05 & 0.02 & 0.02 & 0.03 & 0.02 \\
\hline 414.3 & 0.11 & 0.12 & 0.12 & 0.16 & 0.18 & 0.16 & 0.19 & 0.21 & 0.24 & 0.20 & 0.18 \\
\hline 424.4 & 0.00 & 0.015 & 0.01 & 0.01 & 0.01 & 0.01 & 0.01 & 0.00 & 0.00 & 0.01 & 0.01 \\
\hline 426.2 & 0.06 & 0.05 & 0.08 & 0.07 & 0.07 & 0.07 & 0.10 & 0.04 & 0.05 & 0.06 & 0.05 \\
\hline 440.3 & 0.38 & 0.060 & 0.34 & 0.23 & 0.17 & 0.14 & 0.17 & 0.02 & 0.02 & 0.14 & 0.11 \\
\hline 454.2 & 0.02 & 0.03 & 0.02 & 0.03 & 0.03 & 0.03 & 0.05 & 0.00 & 0.00 & 0.02 & 0.04 \\
\hline 534.3 & 0.02 & 0.00 & 0.03 & 0.01 & 0.02 & 0.00 & 0.00 & 0.00 & 0.00 & 0.00 & 0.00 \\
\hline
\end{tabular}

0, Uninfested leaves; I, Infested leaves; Y, Young uninfested leaves; M, Mature uninfested leaves; $1^{\prime}, 2^{\prime}, 3^{\prime}, 4^{\prime}, 5^{\prime}$, Galls harbouring populations of the first, second, third, fourth, and fifth instars ( $n=50$ each category).

* Source: Sharma et al. ${ }^{65}$.

species involved. These responses depend on the nature of physical and chemical stresses exerted by the inducing insect. Photosynthesis, for instance, is intensely altered in galls because of structural and functional modifications in chloroplasts. Yet, sugar transport from other parts of the same plant occurs mostly, via symplast ${ }^{112}$. Dehiscence of galls and fruits involves similar physiological processes. The dehiscing fruits and galls include newly differentiated specialized cells, and a tight coordination of molecular and biochemical events occurs leading to cell separation freeing seeds in fruits ${ }^{49}$ and the late-stage larva (or adult in some instances) in galls.

\section{Chitinous body parts in gall induction}

The present level of clarity in flowering plants pathogenic fungi interactions is useful in understanding the mechanism of gall induction ${ }^{113,114}$. Qualitative interpretations of the less than $24 \mathrm{~h}$ of gall-inducing insectplant interactions are largely similar to the early phase of attack of plant cells by fungal pathogens. Plant-cell surface enabled with different receptors functionally linked to diverse intra- and intercellular signal pathways facilitates rapid responses to invading fungi. This phase, between a fungus and a susceptible plant, depends on the apoplastic perception of microbe-associated molecular patterns (MAMPs) of the plant ${ }^{111}$. Plants have evolved a mechanism by which they indirectly 'monitor' fungal pathogens via the perception of products that arise during the pathogen's life on the plant ${ }^{115}$. Such monitoring materializes when cell-wall debris accumulates in the affected cell protoplast because of the action of lytic enzymes (e.g. cellulase, xylanase, glucanase) secreted by the fun- gus and consequent wall degeneration at the attacked site. Acting as elicitors, the wall debris provokes a series of metabolic changes in the plant ${ }^{116,117}$. The ability of pathogenic fungi to overcome initial resistance of the plant and establish is noteworthy in the context of gall induction as well. At this stage, the physical action of wounding and the chemical action of discharge of chitin from the insect source are critical factors.

Chitin, a glucosamine polymer, is a key constituent of body parts of insects (e.g. mandibles ${ }^{118}$, ovipositor ${ }^{119}$ ). Plants include chitinases ${ }^{120}$ and are capable of recognizing chito-oligosaccharides from pathogenic fungi during the early infection stage. Introduction of chitin also stimulates mitogen-activated protein kinase (MAPK) cascades and a network of transcription factors ${ }^{121,122}$. Similar to the action of chitin in plant-pathogenic fungi, the chitin discharged by gall-inducing insects into plant cells during gall induction acts as an elicitor ${ }^{123}$. With the discharged chitin from the feeding insect, the host plant cell recruits a downstream pathway negotiating either a susceptible or a resistant response.

Wounding of plant cells by the insect results in rapid modification of the subcellular environment, accompanied by chemical shock triggered by chitin discharged by the attacking insect. Physiological steps characterized in Arabidopsis thaliana (Brassicaeae) wounded by Spodoptera littoralis (Noctuidae) - a non-gall-inducing taxonprovide a credible explanation. When wounded by $S$. littoralis, A. thaliana tissue instantaneously activates two MAPKs: $\mathrm{MAPK}_{3}$ and $\mathrm{MAPK}_{6}$. But this activation is dependent on the upstream MAPKs: $\mathrm{MAPK}_{4}$ and $\mathrm{MAPK}_{5}$, but independent of jasmonic acid ${ }^{124}$. Extending the interpretations made in the $S$. littoralis $-A$. thaliana system to a gall, during inception, activation of specific MAPKs 
possibly occurs and they in turn provoke osmotic changes in the protoplast of the attacked cell, resulting in the earliest recognizable stage in gall induction.

The wounded cell gets activated and turns metaplasied because of the effector proteins discharged from the insect: either from the saliva (e.g. Cecidomyiidae) or from the accessory glands (e.g. Cynipidae). Among the different suggestions explaining the possible chemical triggering the gall $^{85-87}$, the $58 \mathrm{kDa}$ protein shown in S. altissima-E. solodaginis gall ${ }^{85}$ impresses as the most credible. Highly likely, a high-molecular weight protein discharged simultaneously with the chitin triggers the formation of the metaplasied cell, followed by a new morphogenetic pathway to establish the specialized nutritive tissue around it.

Similar to pathogenic fungi, gall-inducing insects can overcome the innate immunity and establish a susceptible response of plants. Here a question whether the gall is a defence response of the plant to limit the localized irritation and damage by the insect or the plant is in active partnership with the insect as a symbiont necessarily arises $^{125}$. Presently, no answer to this question exists, since different studies have answered in support of both ${ }^{126}$.

The resulting metabolic changes stimulated by alterations in the vacuolar $\mathrm{pH}$ - presently referred as 'novel' chemicals of unknown details - diffuse from these dedifferentiated cell(s) into the immediate neighbourhood, but are localized because of their obvious weak nature. This means that the effect does not spread throughout either the involved organ or the plant, explaining why galls and their effects are localized. Relevant here will be to remind us that the term 'toxin' was liberally used in the 1960 s to refer to the secretions (the gall-inducing factors) of gall-inducing insects (e.g. ref. 127). This usage was incorrect, since the physical action of the insect and chemical secretions stimulate growth in the affected tissue and do not kill them, although an insignificant level of necrosis may manifest during early stages in interactions, especially in some species of the less-evolved groups such as the Thysanoptera ${ }^{67}$ and Eriophyoidea ${ }^{128}$. Osmotic changerelated metabolic pressure builds up when gall-inducing insects attack plant cells, activating a train of events in the immediate environment of those plant cells delicately punctured by the feeding or ovipositing insect. The later sequence of events includes alterations in gas exchange and synthesis of growth promotors. Gall induction involves the vigorous uptake of oxygen, stimulating auxin activity. Osmotic stress alters electrical properties of the plasma membrane and impacts on IAA synthesis and activity, which, in turn, alters $\mathrm{H}^{+}$transport ${ }^{129}$. From what we know thus far, it is possible to infer that the plant actively mobilizes energy and nutrients to mitigate the stress and repair the wound from the time of attack by the insect ${ }^{130}$. The insect incidentally utilizes the energy and nutrients mobilized at this site to its advantage.

Carango et al. ${ }^{85}$ in the $1980 \mathrm{~s}$ and Schönrogge et al. ${ }^{131}$ and Hearn et al. ${ }^{132}$ in recent times clarify that the initial- most stage in galls (the metaplasied cell?) is triggered by proteins. No third-party organisms such as virus-like particles have been detected in Biorhiza pallida (Cynipidae)induced galls on $F$. sylvatica ${ }^{132}$. However, Hearn et al. ${ }^{132}$ show many differentially and highly expressed genes in young $B$. pallida larvae encoding secretory peptides - the possible effector proteins - transmitted into $F$. sylvatica. The arabino-galactan proteins of $F$. sylvatica and chitin from $B$. pallida interact in young galls arising on $F$. sylvatica. The $B$. pallida larvae express genes encoding multiple plant cell-wall degrading enzymes.

Plants hosting gall-inducing insects employ varied strategies to neutralize the stress that arises during gall induction and growth-and-differentiation phases. These stress-neutralizing strategies are necessarily dictated by the genetic constitution of plants, but their responses are mediated by molecular changes, varying with the kind of the involved insect. The variation in the strategies could be due to the physiology of action and the nature of chemicals acting in the process. Yet, to generalize, the feeding biology of Cecidomyiidae and the oviposition biology of Cynipidae are useful models. In the context of gall induction, susceptible plants use a flexible, shortterm strategy responding to stress inflicted by the insect. That short-term strategy involves mobilization of energy and other metabolites to the wounded site as a reparative effort to heal the wound, which the inducing insect exploits for its nourishment. This point is fully clear when we realize that the plant returns to its normal physiology the moment the insect ceases to feed. Genetic factors play a role in controlling the shape of the gall, coordinated by the innate correlating morphogenetic factors that operate normally in the plant ${ }^{58}$.

\section{Conclusion}

In spite of unveiling details of several galls and inducing insects of different groups, our understanding of the physiology of gall induction is a conundrum. We are in a state similar to that which existed between the times of Hooke (1660s) on the one hand, and Schleiden and Schwann (1830s) on the other, in explaining the cell ${ }^{133}$. Every biologist interested in explaining gall induction has broached it in the way he/she considered the best using insects of various groups that display varied feeding and oviposition behaviours. Curiously, each of these investigators found an answer and unhesitatingly suggested what they found was 'the' answer to the nagging question.

In short, a generalizable answer to how galls are induced is still elusive. First, we lack a precise definition of a gall. Any abnormality with the involvement of an insect is conveniently, but incorrectly, referred as a gall. Second, from what we know today, a gall induced by a less-evolved insect follows a distinctly different 
developmental process from that induced by a betterevolved insect. Such varied biologies make them ambivalent. A thorough understanding of the basic biological processes occurring during early stages of interaction between the insect and the plant-clarifying the role of chitin supported by carefully designed biochemical and molecular studies - is the immediate need. There are difficulties, of course. Subjecting a metaplasied cell to biochemical quantification using sophisticated instrumentation is hard. A smart combination of in situ exploration using tools such as light-sheet fluorescence and confocal microcopy combined with various omics tools should offer insights into the molecular physiology of the metaplasied cell and the events that follow during the early phase of gall development, answering the long-pending question on how galls are induced. Nevertheless, lookslike we still have a long way to go.

1. Skuhravá, M. and Skuhravý, V., Gall midges (Diptera: Cecidomyiidae) of Italy. Entomologica, 1994, 28, 45-76.

2. Yukawa, J. and Partomihardjo, T., Insect and mite galls collected from Peucang, Panaltan, and the Krakatau Islands, Indonesia. Tropics, 1997, 7, 141-152.

3. Blanche, R., Life in A Gall, CSIRO, Collingwood, Australia, 2012, p. 71.

4. Saleem, U. K. A. and Nasser, M., Insect-induced galls of the Malabar region, Southern India. Orient. Insects, 2015, 49, 165197.

5. Wool, D., Gall-inducing aphids: biology, ecology, and evolution In Biology, Ecology, and Evolution of Gall-inducing Arthropods (eds Raman, A. et al.), Science Publishers, New Hampshire, USA, 2005, pp. 73-132.

6. Costa, J. T., The Other Insect Societies, Harvard University Press, Harvard, 2006, pp. 215-244.

7. Chapman, T. W., Crespi, B. J. and Perry, S. P., The evolutionary ecology of eusociality in Australian gall thrips: a 'model clades' approach. In Ecology of Social Evolution (eds Korb, J. and Heinze, J.), Springer, Heidelberg, 2008, pp. 57-83.

8. Stone, G. N. and Schönrogge, K., The adaptive significance of insect gall morphology. Trends Ecol. Evol., 2003, 18, 512522.

9. Joy, J. B. and Crespi, B. J., Adaptive radiation of gall-inducing insects within a single host-plant species. Evolution, 2007, 61, 784-795.

10. Hardy, N. B. and Cook, L. B., Gall induction in insects: evolutionary dead-end or speciation driver? BMC Evol. Biol., 2010, 10, 1257; http://www.biomedcentral.com/1471-2148/10/257 (accessed on 20 February 2020).

11. Raman, A., Adaptive radiation and diversification in gallinducing insects: search for a pattern. Dtsch. Entomol. Z, 2012, $\mathbf{5 9}, 177-187$.

12. Mani, M. S., Ecology of Plant Galls, W. Junk, The Hague, The Netherlands, 1964, p. 434.

13. Rohfritsch, O., Développement cécidien et rôle du parasite dans quelques galles d'arthropodes. Marcellia, 1971, 37, 233-339.

14. Harper, L. J., Schönrogge, K., Lim, K. Y., Francis, P. and Lichtenstein, C. P., Cynipid galls: insect-induced modifications of plant development create novel plant organs. Plant, Cell Environ., 2004, 27, 327-335.

15. Nysterakis, F., Nouvelle interprétation de la formation des cécidies. C. R. Acad. Sci., 1946, 222, 1133-1134.

16. Nysterakis, F., Zoocécidies et substances de croissance. $C . R$. Soc. Biol., 1947, 141, 1218-1219.
17. Nysterakis, F., Phytohormones et inhibition de la croissance des organes vegetaux attaqués par des aphides. C.R. Acad. Sci., 1948, 226, 746-747.

18. Nysterakis, F., Nouvelles observations sur l'inhibition de la croissance des organes du prunier attaqués par Anuraphis helichrysi. C. R. Acad. Sci., 1948, 226, 831-832.

19. Nysterakis, F., Autres preuves sur la sécrétion d'auxine par certains insects: un nouveau test, trés sensible, pour le dosage des substances de croissance. C. R. Acad. Sci., 1948, 226, 1917-1919.

20. Boysen-Jensen, P., Formation of galls by Mikiola fagi. Physiol. Plant., 1948, 1, 95-108.

21. Guiscarfé-Arillaga, J., Formation of galls in stems and leaves of sugar cane in response to injections of growth regulating substances. Phytopathology, 1949, 39, 489-493.

22. Beck, E. G., The nature of the stimulus in the Solidago gall induced by the larva of Gnorimoschema gallaesolidaginis. Brookhaven Symp. Biol., 1954, 6, 235-251.

23. Nolte, H. W., Untersuchungen über die stofflichen Grundlagen der Gallenbildung. Verh. Dtsch. Ges. Angew. Entomol., 1954, 12, 124-128.

24. Leatherdale, D., Plant hyperplasia induced with a cell-free insect extract. Nature, 1955, 176, 553.

25. Schäller, G., Untersuchungen zur Erzeugung künstlicher Pflanzengallen. Marcellia, 1968, 25, 131-153.

26. Hori, K. and Endo, M., Metabolism of ingested auxins in the bug Lygus disponsi: conversion of indole-3-acetic acid and gibberellin. J. Insect. Physiol., 1977, 23, 1075-1080.

27. Hori, K., Insect secretions and their effect on plant growth, with special reference to hemipterans. In Biology of Insect-induced Galls (eds Shorthouse, J. D. and Rohfritsch, O.), Oxford University Press, New York, USA, 1992, pp. 157-170.

28. Hori, K., Plant growth-regulating factor in the salivary gland of several heteropterous insects. Comp. Biochem. Physiol., B, Biochem., 1976, 53, 435-438.

29. Hori, K., Possible causes of disease symptoms resulting from the feeding of phytophagous Heteroptera. In Heteroptera of Economic Importance (eds Schaefer, C. W. and Panizzi, A. R.), CRC Press, Boca Raton, FL, USA, 2000, pp. 11-35.

30. Braun, A. C., A physiological basis for autonomous growth of the crown-gall tumor cell. Proc. Natl. Acad. Sci. USA, 1958, 44, 344349.

31. Rohfritsch, O. and Shorthouse, J. D., Insect galls. In Molecular Biology of Plant Tumors (eds Kahl, G. and Schell, J. S.), Academic Press, New York, 1982, pp. 131-152.

32. Anders, F., Aminosäuren als gallenerregende Stoffe der Reblaus Viteus [Phylloxera] vitifolii Shimer. Experientia, 1958, 14, 62-63.

33. Miles, P. W., Insect secretions in plants. Annu. Rev. Phytopathol., 1968, 6, 137-164.

34. Küster, E., Die Gallen der Pflanzen, Hirzel, Leipzig, Germany, 1911, p. 437.

35. Sharma, A. et al., Salivary proteins of plant-feeding hemipteroids - implication in phytophagy. Bull. Entomol. Res., 2014, 104, 117-136.

36. Oates, C. N. et al., Insect gallers and their plant hosts: from omics data to systems biology. Int. J. Mol. Sci., 2016, 17(11), 1891; doi:10.3390/ijms17111891 (accessed on 8 March 2020).

37. Thomas, F., Beiträge zur Kenntnis der Milbengallen und Gallmilben. Zeit. Gesam. Wissens., 1873 (1874), 42, 513-537.

38. Meyer, J., Plant Galls and Gall Inducers, Gebrüder Bornträger, Berlin, Germany, 1987, p. 283.

39. Wool, D., Galling aphids: specialization, biological complexity, and variation. Annu. Rev. Entomol., 2004, 49, 175-192.

40. Sharma, A. et al., How do the free-living, lerp-forming, and gall-inducing Aphalaridae (Hemiptera: Psylloidea) affect the nutritional quality of Eucalyptus leaves? Ann. Entomol. Soc. Am., 2016, 109, 127-135. 
41. Maresquelle, H.-J. and Meyer, J., Physiologie et morphogènese des galles d'origine animale (Zoocécidies). Handb. Pflanzenphysiol, 1965, 15(2), 280-329.

42. Meyer, J. and Maresquelle, H.-J., Anatomie des Galles, Gebrüder Bornträger, Berlin, 1983, p. 662.

43. Rohfritsch, O., Morphogenesis und Pflanzengallen. Ber. Deutsch. Bot. Ges., 1977, 90, 339-350.

44. Rohfritsch, O., Patterns in gall development. In Biology of Insectinduced Galls (eds Shorthouse, J. D. and Rohfritsch, O.), Oxford University Press, New York, USA, 1992, pp. 60-80.

45. Meyer, J., Problèmes actuels de cécidologie. Bull. Soc. Bot. Fr., 1969, 116, 445-481.

46. Raman, A., Cecidogenetic behavior of some gall-inducing thrips, psyllids, coccids, and gall midges, and morphogenesis of their galls. Orient. Insects, 2003, 37, 359-413.

47. Raman, A., Morphogenesis of insect-induced plant galls: facts and questions. Flora, 2011, 206, 517-533.

48. Wyss, U., Root parasitic nematodes: an overview. In Cellular and Molecular Aspects of Plant-Nematode Interactions: Developments in Plant Pathology (eds Fenoll, C. et al.), Springer, Dordrecht, 1997, vol. 10, pp. 5-22.

49. McAtee, P. et al., A dynamic interplay between phytohormones is required for fruit development, maturation, and ripening. Front. Plant Sci., 2013, 4, Article 79; doi:https://doi.org/10.3389/ fpls.2013.00079 (accessed 15 April 2020).

50. Bronner, R., Propriétés lytiques des oeufs de Birorhiza pallida O1. C. R. Acad. Sci., 1973, D276, 189-192.

51. Bronner, R., Anatomy of the ovipositor and ovipositional behavior of the gall wasp Diplolepis rosae (Cynipidae, Hymenoptera) Can. Entomol., 1985, 117, 849-858.

52. Yukawa, J. and Rohfritsch, O., Biology and ecology of gallinducing Cecidomyiidae (Diptera). In Biology, Ecology, and Evolution of Gall-inducing Arthropods (eds Raman, A. et al.), Science Publishers, New Hampshire, USA, 2005, pp. 273-304.

53. Rohfritsch, O., Plants, gall midges, and fungi: a three-component system. Entomol. Exp. Appl., 2008, 128, 208-216.

54. Mani, M. S., Plant Galls of India, Science Publishers, New Hampshire, 2000, p. 477.

55. Gagné, R. J. and Jaschhof, M., Update for a Catalog of the Cecidomyiidae (Diptera) of the World, digital version 2, 2014; http://www.ars.usda.gov/SP2UserFiles/Place/12454900/Gagne 2014 World_Cecidomyiidae_Catalog_3rd_Edition.pdf (accessed on 8 December 2019).

56. Sylvén, E., Gall midges (Diptera, Cecidomyiidae) as plant taxonomists. Symb. Botan. Upsal., 1979, XXII, 63-69.

57. Mound, L. A., Taxonomic confusion among gall thrips and host plants, with three new combinations from the genus Austrothrips (Thysanoptera, Phlaeothripidae). Zootaxa, 2020, 4755(3), 587592.

58. Miller, D. G. and Raman, A., Host-plant relations of gallinducing insects. Ann. Entomol. Soc. Am., 2019, 112, 1-19.

59. Raman, A. and Ananthakrishnan, T. N., On the developmental morphology of the rosette galls of Acacia leucophloea Willd. (Mimosaceae) induced by Thilakothrips babuli Ramk. (Thysanoptera: Insecta). Proc. Indian Acad. Sci. Sect. B, 1983, 92, $343-$ 350 .

60. Yang, M. M. et al., Outbreak of erythrina gall wasp on Erythrina spp. (Fabaceae) in Taiwan. Plant Prot. Bull., 2004, 46, 391-396.

61. Kim, I.-K., Evolution of gall-inducing Eulophidae (Hymenoptera: Chalcidoidea) on Myrtaceae in Australia, Ph D thesis, Australian National University, Canberra, 2008, p. 149, https:// openresearch-repository.anu.edu.au/handle/1885/110000 (accessed on 8 December 2019).

62. Gagné, R. J., Revision of Prodiplosis (Diptera: Cecidomyiidae) with description of three new species. Ann. Entomol. Soc. Am., 1986, 79, 235-245.
63. Dhileepan, K. et al., Host associations of gall-inducing Prodiplosis longifila (Diptera: Cecidomyiidae) from Bolivia: implications for its use as a biological control agent for Jatropha gossypiifolia (Euphorbiaceae). Flo. Entomol., 2017, 100, 777-786.

64. Lovett, T. J., Some phytochemical changes in Taxus baccata L. (yew) shoots associated with stages in the life cycle of Taxomyia taxi Inch. Bull. Soc. Bot. Fr. (Actual. Bot.), 1980-1981, 127, 129-136.

65. Sharma, A. et al., Feeding and oviposition behaviour of a gallinducing species of Glycaspis (Synglycaspis) (Hemiptera: Psylloidea: Aphalaridae) and development of galls on the leaves of Eucalyptus macrorhyncha (Myrtaceae) in central western New South Wales, Australia. Eur. J. Entomol., 2015, 112, 75-90.

66. Brooker, M. I. H., A new classification of the genus Eucalyptus L'Hér. (Myrtaceae). Aust. Syst. Bot., 2000, 13, 79-148.

67. Sharma, A. et al., Complex lipids and sterols in the leaves of Eucalyptus macrorhyncha (Myrtaceae) in the context of feeding by an unnamed gall-inducing species of Glycaspis (Synglycaspis) (Hemiptera: Psylloidea: Aphalaridae). Ann. Entomol. Soc. Am., 2016, 109, 890-898.

68. Sharma, A. and Raman, A., Feeding biology and nutritional physiology of Psylloidea (Insecta: Hemiptera): implications in host-plant relations. Curr. Sci., 2017, 113, 1543-1552.

69. Ananthakrishnan, T. N. and Raman, A., Thrips and Gall Dynamics, E. J. Brill, Leiden, The Netherlands, 1989, p. 120.

70. Rohfritsch, O., Relations hôte - parasite au début de la cécidogenèse du Hartigiola annulipes Hartig sur le hêtre. Bull. Soc. Bot. Fr. (Actual. Bot.), 1980-1981, 127, 199-207.

71. Raman, A., Beiderbeck, R. and Herth, W., Early subcellular responses of susceptible and resistant Vitis taxa to feeding by grape phylloxera Daktulosphaira vitifoliae. Bot. Helv., 2009, 119, 31-39.

72. Rey, L., Les prèmiers stades de développement de la galle de Pontania proxima Lep. Bull. Soc. Bot. Fr., 1967, 115, 413-424.

73. Rey, L., Les prèmiers stades du développement de la galle de Biorizha pallida O1. Marcellia, 1969, 36, 119-135.

74. Shorthouse, J. D., Galls induced by cynipid wasps of the genus Diplolepis (Hymenoptera: Cynipidae) on the roses of Canada's grasslands. In Arthropods of Canadian Grasslands: Ecology and Interactions in Grassland Habitats (eds Shorthouse, J. D. and Floate, K. D.), Biological Survey of Canada, Ontario, 2010, I, 251-279.

75. Albersheim, P. et al., Plant Cell Walls, Taylor \& Francis Group, New York, USA, 2010, p. 430.

76. Raman, A., Schaefer, C. W. and Withers, T. M., Galls and gallinducing arthropods: an overview of their biology, ecology, and evolution. In Biology, Ecology, and Evolution of Gall-inducing Arthropods (eds Raman, A. et al.), Science Publishers, New Hampshire, 2005, pp. 1-33.

77. Jiang, F., Zhu, J. and Liu, H.-L., Protoplasts: a useful research system for plant cell biology, especially dedifferentiation. Protoplasma, 2013, 250, 1231-1238.

78. Küster, E., Pathologische Pflanzenanatomie, Gustav Fischer, Jena, Germany, 1903, p. 312.

79. Goldthwaite Jr. C. A., Are stem cells involved in cancer? In Regenerative Medicine, National Institutes of Health, Department of Health and Human Services, USA, August 2006; https:// stemcells.nih.gov/info/Regenerative_Medicine.htm (accessed on 8 February 2020).

80. Steward, F. C., Ammirato, P. V. and Mapes, M. O., Growth and development of totipotent cells. Ann. Bot., 1970, 34, 761-787.

81. Graf, T., Historical origins of transdifferentiation and reprogramming. Cell Stem Cell, 2011, 9, 504-516.

82. Hatchett, J. H., Kreitner, G. L. and Elzinga, R. J., Larval mouthparts and feeding mechanism of the Hessian fly (Diptera: Cecidomyiidae). Ann. Entomol. Soc. Am., 1990, 83, 1137-1147. 
83. Le Relac, A., Rabasse, J. M. and Wajnberg, E., Comparative morphology of the ovipositor of some parasitic Hymenoptera in relation to characteristics of their hosts. Can. Entomol., 1996, 128, 413-433.

84. Dettmer, J. and Friml, J., Cell polarity in plants: when two do the same, it is not the same. Curr. Opin. Cell Biol., 2011, 23, 686696.

85. Carango, P. et al., Induction of a 58,000 Dalton protein during goldenrod gall formation. Biochem. Biophys. Res. Comm., 1988 , 152, 1348-1358.

86. Doss, R. P. et al., Bruchins: insect-derived plant regulators that stimulate neoplasm formation. Proc. Natl. Acad. Sci. USA, 2000, 97, 6218-6223.

87. Farmer, E. E., Potential mitogenic lipids from gall-inducing insects. Trends Plant Sci., 2000, 5, 359-360.

88. Westphal, E., Bronner, R. and Le Ret, M., Changes in leaves of susceptible and resistant Solanum dulcamara infested by the gall mite Eriophyes cladophthirus (Acaria, Eriophyoidea). Can. J. Bot., 1981, 59, 875-882.

89. Breusegem, F. V. and Dat, J. F., Reactive oxygen species in plant cell death. Plant Physiol., 2006, 141, 384-390.

90. Zechmann, B., Ultrastructure of plastids serves as reliable abiotic and biotic stress marker. PLoS ONE, 2019, 14(4), e0214811; https://doi.org/10.1371/journal.pone.0214811 (accessed on 20 July 2020).

91. Gilbert, G. A., Knight, J. D., Vance, C. P. and Allan D. L., Acid phosphatase activity in phosphorus-deficient white lupin roots. Plant Cell Environ., 1999, 22, 801-810.

92. Bronner, R., Contribution à l'étude histochimique des tissus nourriciers des zoocécidies. Marcellia, 1977, 40, 1-134.

93. Bronner, R., The role of nutritive cells in the nutrition of cynipids and cecidomyiids. In Biology of Insect-induced Galls (eds Shorthouse, J. D. and Rohfritsch, O.), Oxford University Press, New York, 1992, pp. 117-192.

94. Apel, K. and Hirt, H., Reactive oxygen species: metabolism, oxidative stress, and signal transduction. Annu. Rev. Plant Biol., 2004, 55, 373-399.

95. Westphal, E., Modification du pH vacuolaire des cellules épidermiques foliares de Solanum dulcamara soumises à l'action d'un acarian cécidogène. Can. J. Bot., 1982, 60, 2882-2888.

96. Westphal, E., Dreger, F. and Bronner, R., The gall mite Aceria cladophthirus (Nalepa). I. Life cycle, survival outside the galls and symptoms' expression on susceptible and resistant Solanum dulcamara L. plants. Exp. Appl. Acarol., 1990, 9, 183-200.

97. Price, P. W., Fernandes, G. W. and Waring, G. L., Adaptive nature of insect galls. Environ. Entomol., 1987, 16, 15-24

98. Diamond, S. E., Blair, C. P. and Abrahamson, W. G., Testing the nutrition hypothesis for the adaptive nature of insect galls: does a non-adapted herbivore perform better in galls? Ecol. Entomol. 2008, 33, 385-393.

99. Heming, B., Structure and function of the mouthparts in larvae of Haplothrips verbasci (Osborn) (Thysanoptera, Tubulifera, Phlaeothripidae). J. Morphol., 1978, 156, 1-37.

100. Raman, A., Gall induction by hemipteroid insects. J. Plant Interact., 2012, 7, 29-44.

101. Raman, A., Two exquisite hemipteran galls of India with notes on the physiology of gall induction by Sternorrhyncha, Entomon, 2016, 41, 251-264

102. Raman, A. and Ananthakrishnan, T. N., On the developmental morphology of the leaf fold galls of Maytenus senegalensis (Lam) Excel., (Celastraceae), induced by Alocothrips hadrocerus (Karny) (Thysanoptera: Insecta). Proc. Indian Acad. Sci. Sect. B 1979, 88(B), 103-107.

103. Florentine, S. K., Raman, A. and Dhileepan, K., Effects of gall induction by Epiblema strenuana on gas exchange, nutrients, and energetics in Parthenium hysterophorus. BioControl, 2005, 50, $787-801$
104. St. John, M. G. and Shorthouse, J. D., Allocation patterns of organic nitrogen and mineral nutrients within stem galls of Diplolepis spinosa and Diplolepis triforma (Hymenoptera: Cynipidae) on wild roses (Rosaceae). Can. Entomol., 2000, 132, 635-648.

105. Kirst, G. O. and Rapp, H., Zur Physiologie der Galle von Mikiola fagi Htg. auf Blättern von Fagus sylvatica L. 2. Transport ${ }^{14} \mathrm{C}$ markierter Assimilate aus dem befallenen Blatt und aus Nachbarblättern in die Galle. Biochem. Physiol. Pflanz., 1974, 165, 445455.

106. Raman, A. et al., Metabolite mobilization in the stem galls of Parthenium hysterophorus induced by Epiblema strenuana inferred from the signatures of isotopic carbon and nitrogen and concentrations of total non-structural carbohydrates. Entomol. Exp. Appl., 2006, 119, 101-107.

107. Byers, J. A., Brewer, J. W. and Denna, D. W., Plant growth hormones in pinyon insect galls. Marcellia, 1976, 39, 125-134.

108. Yamaguchi, H. et al., Phytohormones and willow gall induction by a gall-inducing sawfly. New Phytol., 2012, 196, 586-595.

109. McCalla, D. R., Genthe, M. K. and Hovanitz, W., Chemical nature of an insect gall growth-factor. Plant Physiol., 1962, 37, 98-103.

110. Mapes, C. C. and Davies, P. J., Indole-3-acetic acid and ball gall development on Solidago altissima. New Phytol., 2001, 151, 195202.

111. Tooker, J. F. and De Moraes, C. M., A gall-inducing caterpillar species increases essential fatty acid content of its host plant without concomitant increases in phytohormone levels. Mol. Plant-Microbe Interact, 2009, 22, 551-559.

112. Palma, J. M. et al., Fruit ripening: from present knowledge to future development. Front. Plant Sci., 2019; https://doi.org/ 10.3389/fpls.2019.00545 (accessed on 25 July 2020)

113. Arenas, Y. A. et al., Functional analysis and mode of action of phytotoxic Nep1-like proteins of Botrytis cinerea. Physiol. Plant Pathol., 2010, 74, 376-386.

114. Siewers, V. et al., Functional analysis of the cytochrome $\mathrm{P}_{450}$ monooxygenase gene bcbot1 of Botrytis cinerea indicates that botrydial is a strain-specific virulence factor. Mol. Plant-Microbe Interact., 2005, 18, 602-612.

115. Newman, M.-A. et al., MAMP (microbe-associated molecular pattern) triggered immunity in plants, Front. Plant Sci., doi:10.3389/fpls.2013.00139 (accessed on 10 March 2020).

116. Agrawal, G. K. et al., Plant organelle proteomics: collaborating for optimal cell function. Mass Spectrom. Rev., 2011, 30, 772-853.

117. Gozzo, F. and Faoro, F., Systemic acquired resistance (50 years after discovery): moving from the lab to the field. J. Agric. Food Chem., 2013, 61, 12473-12491.

118. Solinas, M., Morfologia, anatomia e organizzazione funzionale del capo della larva matura de Phaenobremia aphidimyza (Rondani). Entomologica, 1968, 4, 7-44.

119. Cerkvenik, U. et al., Stiffness gradients facilitate ovipositor bending and spatial probing control in a parasitic wasp. J. Exp. Biol., 2019, 222, jeb195628, doi:10.1242/jeb.195628 (accessed on 20 April 2020).

120. Collinge, D. B. et al., Plant chitinases. Plant J., 1993, 3, 31-40.

121. Pusztahelyi, T., Chitin and chitin-related compounds in plantfungal interactions. Mycology, 2018, 9, 189-201.

122. Wan, J., Zhang, X.-C. and Stacey, G., Chitin signaling and plant disease resistance. Plant Signal. Behav., 2008, 3, 831-833.

123. Shamshina, J. L., Oldham, T. and Rogers, R. D., Applications of chitin in agriculture. In Sustainable Agriculture Reviews 36, Chitin and Chitosan in Food, Agriculture, Pharmacy, Medicine, and Waste Water Treatment (eds Crini, G. and Lichtfouse, E.), Springer Nature, Cham, Switzerland, 2019, pp. 125-146.

124. Schweitzer, F. et al., Differential contribution of transcription factors to Arabidopsis thaliana defense against Spodoptera littoralis. Front. Plant Sci., 2013; https://doi.org/10.3389/fpls.2013. 00013 (accessed on 14 July 2020). 


\section{REVIEW ARTICLE}

125. Raman, A., Visionary words and realistic achievements: one hundred years of cecidology. Formos. Entomol., 2018, 38, 5-24.

126. Harris, M. O. and Pitzschke, A., Plants make galls to accommodate foreigners: some are friends, most are foes. New Phytol. 2020, 225, 1852-1872.

127. Carter, W., Insects in Relation to Plant Disease, Interscience (Wiley), New York, USA, 1962, p. 705.

128. Westphal, E. and Manson, D. C. M., Feeding effects on host plants: gall formation and other distortions. World Crop Pests, 1996, 6, 231-242.

129. Miles, P. W., Aphid saliva. Biol. Rev., 1999, 74, 41-85.

130. León, J., Rojo, E. and Sánchez-Serrano, J. J., Wound signalling in plants. J. Exp. Bot., 2001, 52, 1-9.

131. Schönrogge, K. et al., Reprogramming plant development: two approaches to study the molecular mechanism of gall formation. In The Biology of Gall-inducing Arthropods, General Technical Report NC 199 (eds Csóka, W. et al.), USDA Forest Service, St. Paul, Minnesota, USA, 1998, pp. 153-160.

132. Hearn, J. et al., Genomic dissection of an extended phenotype: oak galling by a cynipid gall wasp, PLoS Genet., 2019, 15(11), e1008398; https://doi.org/10.1371/journal.pgen.1008398 (accessed on 22 May 2020).

133. Wolpert, L., Evolution of the cell theory. Philos. Trans. Biol. Sci., 1995, 349, 227-233.
134. Raman, A., Burckhardt, D. and Harris, K. M., Biology and adaptive radiation in the gall-inducing Cecidomyiidae (Insecta Diptera) and Calophyidae (Insecta Hemiptera) on Mangifera indica (Anacardiaceae) in the Indian subcontinent. Trop. Zool., 2009, 22, 27-56.

135. Burckhardt, D., Sharma, A. and Raman, A., Checklist and comments on the jumping plant-lice (Hemiptera: Psylloidea) from the Indian subcontinent. Zootaxa, 2018, 4457(1), 1-38.

ACKNOWLEDGEMENTS. I thank Laurence Mound (Australian National Insect Collection, CSIRO, Canberra, Australia), Soundararajan Madhavan (University of Nebraska, Lincoln, USA), and Krishnappa Chandrashekara (University of Agricultural Sciences, Bengaluru) for reviewing the final draft of this manuscript and Anamika Sharma (IPM Innovation Lab, Virginia Tech, Blacksburg, USA) for help in organizing the images.

Received 16 October 2020; accepted 2 November 2020

doi: $10.18520 / \mathrm{cs} / \mathrm{v} 120 / \mathrm{i} 1 / 66-78$ 